\title{
Heat Loss and Exergy Flow through Respiration of the Human Body under Different Meteorological Conditions
}

\author{
M. Bilgili', B. Sahin², E. Simsek³ ${ }^{3}$ A. Ozbek¹, A. Yasar ${ }^{1 *}$ \\ 'Cukurova University, Ceyhan Engineering Faculty, Mechanical Engineering Department, 01950, Adana, Turkey \\ ${ }^{2}$ Cukurova University, Engineering Faculty, Mechanical Engineering Department, 01330, Adana, Turkey \\ ${ }^{3}$ Cukurova University, Adana Vocational School of Higher Education, 01160, Adana, Turkey
}

M. Bilgili (0000-0002-5339-6120), B. Sahin(0000-0003-0671-0890), E. Simsek(0000-0002-5442-068X), A. Ozbek(0000-0003-1287-9078), A. Yasar(0000-0001-2345-6789)

\begin{abstract}
In this study, monthly evaporative and convective heat losses and exergy flow that occur as a result of respiration were determined for human bodies in states of light and heavy activity levels, and comparisons of the results obtained were executed according to different meteorological conditions and regions. For this purpose, seven different climate zones (CZ-1, CZ-2, CZ-3, CZ-4, CZ-5, CZ-6 and CZ-7) were selected in Turkey. Meteorological parameters such as atmospheric temperature, atmospheric pressure and relative humidity were used for energy and exergy analyses. According to the obtained results, total heat loss and exergy flow through respiration of the human body demonstrated considerable variations seasonally depending on the climate zones. The highest heat loss and exergy flow values were determined in the region of continental climate (CZ-2), while the lowest heat loss and exergy flow values were obtained in the region of Mediterranean climate (CZ-5). For a human body engaging in light activity in a hot climate zone, the exhaled air temperature, specific humidity and relative humidity values were determined as $35.11{ }^{\circ} \mathrm{C}, 0.0333 \mathrm{~kg} \mathrm{H}_{2} \mathrm{O} / \mathrm{kg}$ dry air and $91.3 \%$, respectively.
\end{abstract}

Keywords: Climate zone; Environmental differences; Exergy flow; Human physiology; Metabolism; Meteorological Conditions; Respiratory heat loss.

\section{INTRODUCTION}

The human body can produce heat within the range of 100 $\mathrm{W}$ and $1000 \mathrm{~W}$, depending on the activity level of the body. The level of human body activity causes increment in the amount of body heat produced. However, whatever the variation in ambient conditions may be, it is essential that the body's vital functions be maintained so as to preserve the internal body temperature within a certain range. In extremely hot and extremely cold environments, the human body temperature range may vary slightly $[1,2]$. The internal temperature of the human body under normal conditions should remain between $36.5^{\circ} \mathrm{C}$ and $37.5{ }^{\circ} \mathrm{C}$, while the skin surface temperature should vary within the range of $31.5^{\circ} \mathrm{C} \leq \mathrm{t}_{\mathrm{sk}} \leq$ $33.5^{\circ} \mathrm{C}$. To sustain vital functions of the bodily organs, the body must stay within this narrow range of temperature. Moreover, this temperature range secures the comfort and health of the body. However, when the core temperature of the human body decreases below $35{ }^{\circ} \mathrm{C}$ or increases above $39^{\circ} \mathrm{C}$, the performance of the human body begin to diminish. Core temperatures that drop below $31{ }^{\circ} \mathrm{C}$ or rise above
$43{ }^{\circ} \mathrm{C}$ can be fatal [3].

The portion of the heat generated via metabolism, which cannot be converted into active use, must be released from the body into the surroundings. Basically, this heat transfer occurs in the form of convective and evaporative heat $[4,5]$. Heat is transmitted from the interior of the body to the skin surface by conduction and convection, and from the skin into the surroundings by conduction, convection and radiation [6]. The evaporative heat transfer through the skin occurs by means of the sweat diffused from the skin as moisture, which evaporates from the skin surface. The rate of this evaporative heat transfer depends on water vapor pressure, temperature difference between skin surface and atmosphere, and air velocity [1]. The other form of evaporative heat transfer occurs through reduction of the internal temperature of the body by inhalation. Heat is first conveyed from the environment to the inner region of body by inhalation before being released to the environment from the interior of body as convective and evaporative heat $[7,8] .90 \%$ of heat is released from the skin of the human body, while the 
remaining $10 \%$ is released via the respiratory system. Given the influence a decrease in evaporative heat loss through respiratory has on temperature gradients between the cranium and thorax, the hyperthermia-induced heat loss from the upper airways could have an impact on brain temperatures. For this reason, analysis of heat loss and exergy flow occurring through respiration of the human body is a vital concern in terms of thermal comfort and health [9].

All of the organisms are generally influenced by the climatic factors. So, the human body tries to adjust itself to the environmental condition. In this regard, there is a need for the thermal comfort which establishes a connection between the external thermal stress and the human thermoregulation capacities such as heat loss and heat storage. Thermal comfort refers to the feeling of being neither too cold nor too warm when attired in clothing of appropriate thickness. In terms of securing comfort and productivity, thermal comfort is a key element. The human body experiences thermal comfort and feel better when the body's excess heat is transferred to the environment in an easy and permanently recurring manner. As the human body is very sensitive to the ambient temperature, body temperature must be preserved within a narrow temperature range in order to provide comfort; in other words, within a somewhat wider range of ambient temperatures, a person feels uncomfortable under thermal stress. So, defining this optimum thermal comfort as a standard condition for human living in buildings is very important [4].

Exergy analysis based on first and second laws of thermodynamics describes a complete working process of system including destruction and entropy generation considering the reference temperature [4]. Human body exergy destruction can be utilized to define the state of human performance under different meteorological conditions [10]. In this study, the total (convective and evaporative) heat loss and exergy flow that occur by inhalation were calculated for individuals performing light and heavy activity levels in different meteorological conditions and regions. Additionally, this study investigated the effect that variations in the ambient temperature, relative and specific humidity and atmospheric pressure have on the total heat loss and exergy flow, and comparisons were made for the total (convective and evaporative) heat loss and exergy flow resulting from respiration in different seasons and regions. Variations in the amount of specific humidity and temperature of exhaled air converted from the interior of body by respiration were also examined. The results obtained from this present study may be used as a reference for a detailed study of climatization applications.

\section{MATERIALS AND METHODS}

\subsection{Energy Balance Model of the Human Body}

The heat transfer that takes place from the inner surface of the human body toward the skin surface is achieved through convection and conduction (blood flow from internal regions toward skin tissue), as shown in Figure 1.

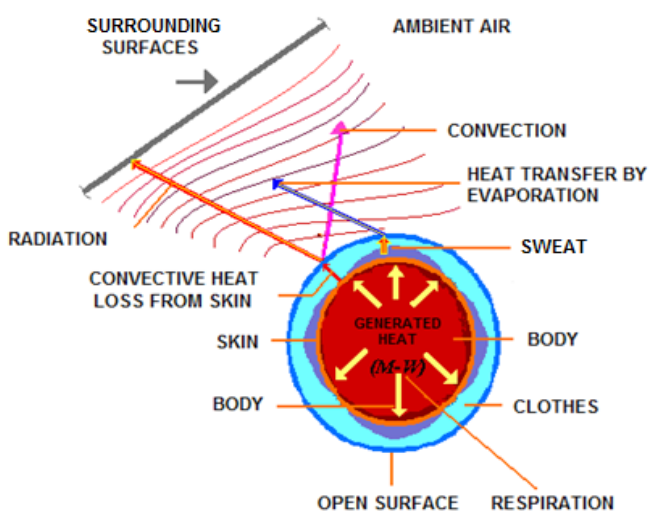

Figure 1. Heat transfer between the surface of the human body and atmospheric air

This fluid movement (mass transfer) results in the droplets formation of sweat on the skin's surface; evaporation of the sweat fluid comes out heat transfer into the external environment [7]. The heat produced must be equal to the heat transferred to the environment to protect the body thermal balance. In the event that the body is exposed to a hot environment, the thermoregulation system serves to minimize the transfer of heat to the body [11]. Tissue temperatures are maintained at biologically safe levels to allow for optimal chemical reactions to occur. The thermoregulation system manages these levels by adjusting the heat transfer rates of conduction and convection between the skin surface and environment. Therefore, basal temperature distribution is regulated by rate of heat transferred from the tissue, heat rate conveyed via blood to the skin and heat transfer rate between the skin surface and environment [12]. In this way, the body's thermal balance is able to remain decidedly stable. If the heat generated as a result of metabolic reactions is not offsetted by the heat transferred from the skin surface to the environment, body temperature either increases or decreases. Steady-state energy balance and instant energy balance models are widespread utilized to examine convective heat transfer between human body and environment.

\subsection{Steady-State Energy Balance Model}

In the steady-state energy balance model presented by Fanger [15,16], when the body is in a state of heat balance, the energy storage in the body is considered to be negligible. Since the body and the skin are treated as a single component, the processes of shivering and blood flow control are not taken into consideration. Therefore, the body temperature under this model does not change over time. Rather, energy that is unable to be converted into active use by metabolism is transferred from the body by the skin surface and respiration in order to establish energy balance. This energy balance is expressed in the equation shown below $[10,13,17]$ :

$$
\begin{aligned}
& M-W=Q_{s k}+Q_{\text {res }}= \\
& \left(C+R+E_{s k}\right)+\left(C_{\text {res }}+E_{\text {res }}\right)
\end{aligned}
$$

The unit of $\mathrm{W} / \mathrm{m}^{2}$ is valid in all terms. $M$ denotes the rate of metabolic energy production, $W$ designates the rate of me- 
chanical work, $Q_{s k}$ is the total heat loss rate from the skin, $Q_{r e s}$ is the total heat loss rate through respiration, $C$ is the convective heat loss rate from the skin, $R$ is the radiative heat loss rate from the skin, $E_{s k}$ is the total evaporative heat loss rate from the skin, $C_{\text {res }}$ is the convective heat loss rate from respiration and $E_{\text {res }}$ is the evaporative heat loss rate resulted from respiration.

\subsection{Heat Loss from the Body through Respiration}

During inhalation, the air breathed into the body receives convective and evaporative heat as a result of convection and evaporation. A significant amount of heat transfer may occur during respiration, for air is inhaled within certain environmental conditions and expelled, at a temperature just below the internal body temperature, as saturated air. Convective and evaporative heat losses related with respiration are given by the following equations:

$$
\begin{aligned}
& C_{\text {res }}=\frac{\dot{m}_{r e s} C_{p, a}\left(T_{e x}-T_{a}\right)}{A_{D}} \\
& E_{\text {res }}=\frac{\dot{m}_{r e s} h_{f g}\left(W_{e x}-W_{a}\right)}{A_{D}}
\end{aligned}
$$

In these equations, $m_{\text {res }}(\mathrm{kg} / \mathrm{s})$ denotes inhaled air flow rate, $W_{e x}\left(\mathrm{~kg} \mathrm{H}_{2} \mathrm{O} / \mathrm{kg}\right.$ dry air $)$ is the specific humidity of exhaled air, $T_{e x}\left({ }^{\circ} \mathrm{C}\right)$ is expelled air temperature, $W_{a}\left(\mathrm{~kg} \mathrm{H}_{2} \mathrm{O} / \mathrm{kg}\right.$ dry air) is specific humidity of the inhaled ambient air, $C_{p, a}(\mathrm{~kJ} /$ $\mathrm{kg} . \mathrm{K})$ is the specific heat capacity of ambient air, $T_{a}\left({ }^{p} \mathrm{C}\right)$ is the ambient air temperature and $h_{f g}(\mathrm{~kJ} / \mathrm{kg} . \mathrm{K})$ is the evaporative heat of the vaporization of water. The naked body's DuBois surface area is designated by $A_{D}\left(\mathrm{~m}^{2}\right)$ and computed as:

$$
A_{D}=0.202 m^{0.25} l^{0.775}
$$

Here, $\mathrm{m}(\mathrm{kg})$ denotes the individual's mass, and $\mathrm{l}(\mathrm{m})$ is the individual's height. The values of the parameters used in the equation stated above can be simplified by expressing the approximate or empirical correlations. Under normal circumstances, the inhaled air flow is largely a function of the metabolic rate and is given by the following relations.

$$
\dot{m}_{\text {res }}=K_{\text {res }} . M
$$

In this relation, $K_{\text {res }}$ is a proportioning constant $\left(2.58 \mathrm{~kg} \cdot \mathrm{m}^{2} /\right.$ MJ). Exhaled air is almost saturated and has a temperature close to body temperature. The empirical equation developed by Fanger (1982) [6] is used to identify the state of air under regular internal environmental conditions.

$$
\begin{aligned}
& T_{e x}=32.6+0.066 T_{a}+32 W_{a} \\
& W_{e x}=0.0277+0.000065 T_{a}+0.2 W_{a}
\end{aligned}
$$

The specific humidity of ambient air, using the total pressure $P_{t}(\mathrm{kPa})$ and the water vapor pressure $P_{a}(\mathrm{kPa})$ of ambient air, can be written in the following form:

$$
W_{a}=0.622 P_{a} /\left(P_{t}-P_{a}\right)
$$

\subsection{Exergy Flow through Respiration}

Considering the physical exergy of humid air, the total exergy flow through the respiration can be defined by equation below [10]:

$$
\begin{aligned}
& E x_{r e s}=\frac{\dot{m}_{r e s}}{A_{D}}\left\{\left(C_{p, a}+W_{e x} C_{p, v}\right)\left[\left(T_{e x}-T_{a}\right)-T_{a} \ln \frac{T_{e x}}{T_{a}}\right]\right. \\
& \left.+R_{a} T_{a}\left[\left(1+1.608 W_{e x}\right) \ln \frac{1+1.608 W_{a}}{1+1.608 W_{e x}}+1.608 W_{e x} \ln \frac{W_{e x}}{W_{a}}\right]\right\}
\end{aligned}
$$

where $C_{p, v}$ is the specific heat capacity of water vapor $(=1872.3 \mathrm{~J} / \mathrm{kg} \cdot \mathrm{K})$.

\section{RESULTS AND DISCUSSION}

Environmental factors, such as ambient temperature, relative humidity, specific humidity, wind speed and atmospheric pressure, are among the most important factors used for determining the thermal equilibrium of the human body. The individual envisioned for the study has a mass of $70 \mathrm{~kg}$ and a height of $1.73 \mathrm{~m}$. The temperatures of individual's internal body and skin are kept at $36.8^{\circ} \mathrm{C}$ and $33.7^{\circ} \mathrm{C}$, respectively, with respect to the steady-state energy balance model. The DuBois surface area of the individual was determined to be $1.8 \mathrm{~m}^{2}$. The seven geographic regions of Turkey, such as Samsun, Erzurum, Eskisehir, Sanllurfa, Adana, Izmir and Tekirdag provinces, were selected for the purpose of using different climate conditions to analyze the heat transferred from the human body by means of respiration and are given in Figure 2. These selected provinces reflect the average climatic conditions of each geographic area. Therefore, seven different climate zones (CZ-1, CZ-2, CZ-3, CZ-4, CZ-5, CZ-6 and CZ-7) in Turkey were selected. Table 1 gives the climate classes, climate zones and climate conditions of provinces. Meteorological parameters such as atmospheric temperature, relative humidity and atmospheric pressure in the selected climate zones were given in Tables 2-4. For metabolic heat energy production of an individual having the same physical properties, the values of energy production between the light activity level $\left(1 \mathrm{Met}=58.2 \mathrm{~W} / \mathrm{m}^{2}\right)$ and the heavy activity level $\left(4 \mathrm{Met}=349.2 \mathrm{~W} / \mathrm{m}^{2}\right)$ were used. Convective and evaporative heat losses that occur from the human body by inhalation were determined by taking the effect of environmental factors and physiological characteristics into account.

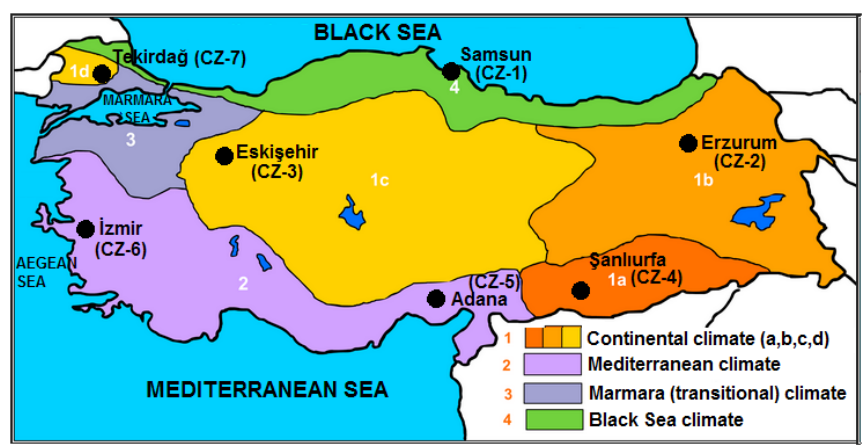

Fig. 2 Turkey's climate types and, provinces of Turkey's seven geographical regions

Table 1. Climate classes and climatic conditions of provinces

\begin{tabular}{|l|l|l|l|l|}
\hline $\begin{array}{l}\text { Climate } \\
\text { zone }\end{array}$ & Province & $\begin{array}{l}\text { Climate } \\
\text { property }\end{array}$ & $\begin{array}{l}\text { Climate } \\
\text { class }\end{array}$ & Climate condition \\
\hline CZ-1 & Samsun & Humid & $\begin{array}{l}\text { Black Sea } \\
\text { climate }\end{array}$ & $\begin{array}{l}\text { All seasons are wet. It has Oceanic } \\
\text { or temperate climate. }\end{array}$ \\
\hline CZ-2 & Erzurum & $\begin{array}{l}\text { Semi dry- } \\
\text { less humid }\end{array}$ & $\begin{array}{l}\text { Continen- } \\
\text { tal climate }\end{array}$ & Winter is long, cold and snowy. \\
\hline
\end{tabular}




\begin{tabular}{|l|l|l|l|l|}
\hline CZ-3 & Eskişehir & Semi dry & $\begin{array}{l}\text { Continen- } \\
\text { tal climate }\end{array}$ & $\begin{array}{l}\text { Winter is long, cold and snowy. } \\
\text { Summer is short and hot. }\end{array}$ \\
\hline CZ-4 & Şanlıurfa Semi dry & $\begin{array}{l}\text { Continen- } \\
\text { tal climate }\end{array}$ & $\begin{array}{l}\text { Winter is long, cold and snowy. } \\
\text { Summer is short and hot }\end{array}$ \\
\hline CZ-5 & Adana & $\begin{array}{l}\text { Semi dry- } \\
\text { less humid }\end{array}$ & $\begin{array}{l}\text { Mediter- } \\
\text { ranean } \\
\text { climate }\end{array}$ & $\begin{array}{l}\text { A climate distinguished by warm, } \\
\text { wet winters under prevailing } \\
\text { westerly winds and calm, hot, dry } \\
\text { summers. }\end{array}$ \\
\hline CZ-6 & Izmir & $\begin{array}{l}\text { Semi dry- } \\
\text { less humid }\end{array}$ & $\begin{array}{l}\text { Mediter- } \\
\text { ranean } \\
\text { climate }\end{array}$ & $\begin{array}{l}\text { A climate distinguished by warm, } \\
\text { wet winters under prevailing } \\
\text { westerly winds and calm, hot, dry } \\
\text { summers. }\end{array}$ \\
\hline CZ-7 & Tekirdağ & $\begin{array}{l}\text { Semi dry- } \\
\text { less humid }\end{array}$ & $\begin{array}{l}\text { Marmara } \\
\text { (transi- } \\
\text { tional) } \\
\text { climate }\end{array}$ & $\begin{array}{l}\text { A transitional climate between a } \\
\text { temperate Mediterranean climate } \\
\text { and a temperate Oceanic climate } \\
\text { is dominant. It is hot and dry in } \\
\text { summers and cool, cold and wet in } \\
\text { winters. }\end{array}$ \\
\hline
\end{tabular}

Table 2. Mean atmospheric temperatures $\left({ }^{\circ} \mathrm{C}\right)$ of climate zones

\begin{tabular}{|c|c|c|c|c|c|c|c|}
\hline Month & CZ-1 & CZ-2 & CZ-3 & CZ-4 & CZ-5 & CZ-6 & CZ-7 \\
\hline January & 7.35 & -11.63 & -0.44 & 5.89 & 9.15 & 8.84 & 4.71 \\
\hline February & 7.06 & -8.69 & 0.66 & 7.21 & 10.33 & 9.36 & 5.21 \\
\hline March & 8.55 & -2.10 & 5.39 & 11.88 & 13.93 & 12.50 & 8.19 \\
\hline April & 10.96 & 5.25 & 9.74 & 16.24 & 17.68 & 16.29 & 11.81 \\
\hline May & 15.60 & 10.63 & 15.09 & 22.86 & 22.26 & 21.36 & 16.99 \\
\hline June & 20.68 & 15.11 & 19.44 & 29.16 & 26.35 & 26.31 & 21.51 \\
\hline July & 24.18 & 19.58 & 22.65 & 33.00 & 28.85 & 28.91 & 24.71 \\
\hline August & 24.91 & 19.63 & 22.31 & 31.81 & 29.05 & 28.56 & 24.70 \\
\hline September & 20.96 & 14.15 & 17.05 & 27.04 & 26.28 & 23.93 & 20.33 \\
\hline October & 16.84 & 7.80 & 11.74 & 20.69 & 21.84 & 19.43 & 15.89 \\
\hline November & 12.28 & -0.29 & 5.43 & 12.49 & 14.93 & 13.96 & 10.96 \\
\hline December & 8.53 & -8.10 & 0.50 & 7.19 & 10.33 & 10.10 & 6.34 \\
\hline
\end{tabular}

Table 3. Mean relative humidity (\%) of climate zones

\begin{tabular}{|c|c|c|c|c|c|c|c|}
\hline Month & CZ-1 & CZ-2 & CZ-3 & CZ-4 & CZ-5 & CZ-6 & CZ-7 \\
\hline January & 65.98 & 76.96 & 72.59 & 70.65 & 69.21 & 69.74 & 82.54 \\
\hline February & 67.74 & 75.10 & 68.89 & 68.20 & 69.20 & 67.99 & 80.90 \\
\hline March & 73.29 & 73.31 & 59.55 & 59.34 & 68.79 & 65.33 & 79.46 \\
\hline April & 79.39 & 67.31 & 57.46 & 59.58 & 68.64 & 65.06 & 78.67 \\
\hline May & 79.86 & 62.26 & 53.91 & 47.16 & 66.85 & 62.81 & 75.23 \\
\hline June & 74.84 & 56.18 & 48.03 & 35.74 & 67.53 & 54.33 & 72.14 \\
\hline July & 74.21 & 50.80 & 45.99 & 33.58 & 73.96 & 52.73 & 70.59 \\
\hline August & 75.05 & 49.08 & 49.29 & 41.59 & 73.91 & 56.24 & 72.86 \\
\hline September & 77.35 & 50.23 & 54.93 & 42.26 & 67.31 & 62.23 & 77.19 \\
\hline October & 75.91 & 65.85 & 61.60 & 52.18 & 62.78 & 64.67 & 79.56 \\
\hline November & 69.54 & 72.16 & 68.05 & 61.34 & 65.24 & 69.61 & 83.17 \\
\hline December & 66.15 & 76.73 & 72.88 & 67.63 & 66.93 & 70.89 & 82.71 \\
\hline
\end{tabular}

The monthly variations of heat transfer and exergy flow occurring by respiration under different climate conditions for metabolic heat energy production of 1 Met are illustrated in Figure 3. As seen, the highest value of heat transfer took place by respiration in the CZ-2 (Erzurum province), while the lowest heat transfer took place in the CZ-5 (Adana province). The reason for this is that the ambient temperature and specific humidity of the CZ-2 are lower than those found in the CZ-5. As expected for all zones, heat transfer via respiration decreased in the summer months and increased in winter months. As clearly shown that the highest exergy flows through respiration were observed in January, as the ambient temperature during this month was also lower than the ambient temperatures during the other months. The
Table 4. Mean atmospheric pressure (hpa) of climate zones

\begin{tabular}{|c|c|c|c|c|c|c|c|}
\hline Month & CZ-1 & CZ-2 & CZ-3 & CZ-4 & CZ-5 & CZ-6 & CZ-7 \\
\hline January & 1019.33 & 822.70 & 926.33 & 953.81 & 1015.29 & 1013.47 & 1019.80 \\
\hline February & 1017.70 & 821.18 & 924.54 & 952.39 & 1013.48 & 1012.89 & 1018.24 \\
\hline March & 1017.31 & 821.35 & 924.24 & 950.79 & 1011.75 & 1011.97 & 1017.30 \\
\hline April & 1014.89 & 821.25 & 922.73 & 948.75 & 1009.04 & 1008.96 & 1014.27 \\
\hline May & 1014.71 & 822.85 & 923.88 & 947.70 & 1007.85 & 1009.07 & 1015.44 \\
\hline June & 1014.11 & 822.69 & 924.33 & 944.71 & 1005.56 & 1008.00 & 1014.97 \\
\hline July & 1011.56 & 822.23 & 922.55 & 941.50 & 1002.49 & 1005.06 & 1012.29 \\
\hline August & 1011.83 & 822.78 & 922.84 & 942.66 & 1003.54 & 1005.59 & 1012.53 \\
\hline September & 1015.39 & 824.63 & 925.53 & 947.33 & 1007.63 & 1009.74 & 1015.44 \\
\hline October & 1018.18 & 826.30 & 927.69 & 951.66 & 1011.63 & 1012.90 & 1018.59 \\
\hline November & 1019.20 & 825.69 & 927.81 & 953.69 & 1014.96 & 1014.44 & 1019.34 \\
\hline December & 1020.84 & 824.49 & 928.01 & 954.65 & 1016.48 & 1015.07 & 1020.84 \\
\hline
\end{tabular}

lowest exergy flows were found to occur in the month of July. When analyzed by climatology, the highest exergy flow values are in the region of continental climate, while the lowest exergy flow values are in the region of Mediterranean climate.

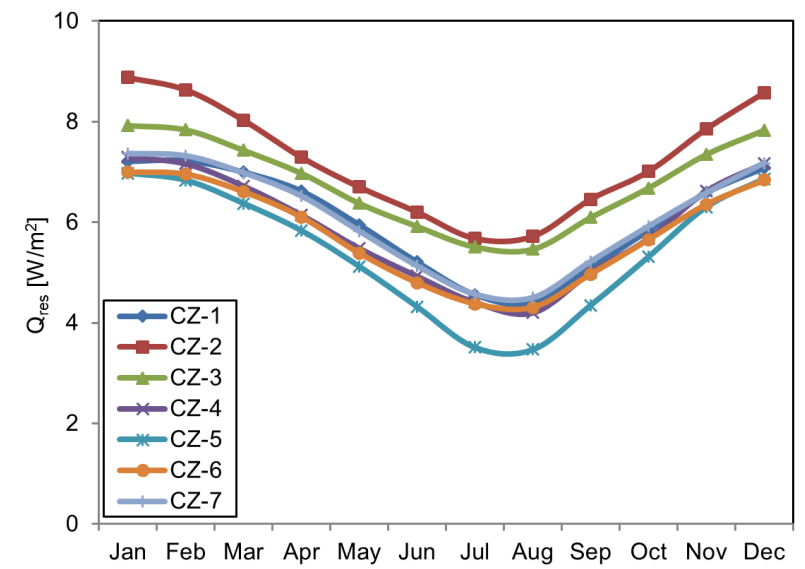

(a)

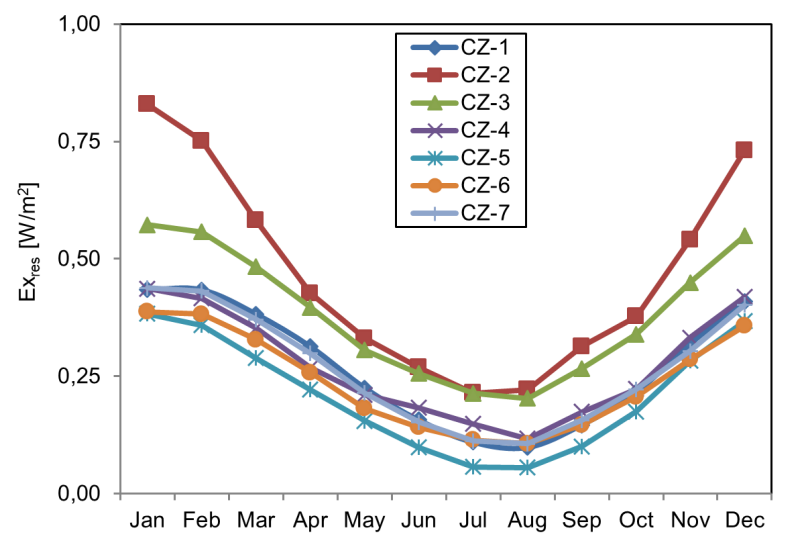

(b)

Figure 3. The monthly variation of (a) heat loss (b) exergy flow through respiration for 1 Met

The monthly variation in the exhaled air temperature released for metabolic heat energy production of 1 Met in different climate zones is shown in Figure 4. 


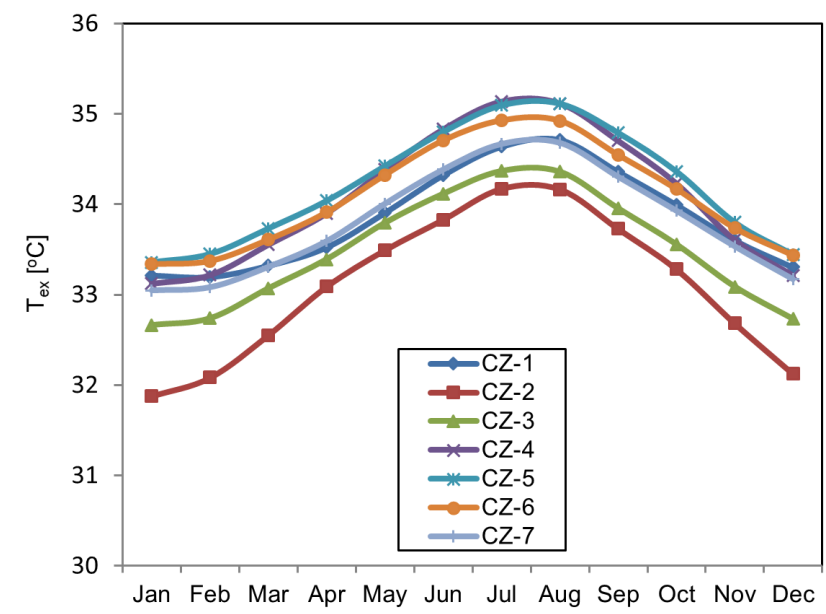

Figure 4. The monthly variation of exhaled air temperature for 1 Met.

Exhaled air temperature was higher in July and August compared to the other months, with the temperature values varying between $34.17^{\circ} \mathrm{C}$ and $35.13^{\circ} \mathrm{C}$. The individual's body internal body temperature, nonetheless, remained constant at $36.8^{\circ} \mathrm{C}$. The exhaled air temperature reached the highest value in the CZ-5, which has a Mediterranean climate, and the lowest value in the Continental climate (CZ-2).

The monthly variation in specific exhaled air humidity in different climatic zones for metabolic heat energy production of 1 Met is presented in Figure 5. As seen from the figure, the specific exhaled air humidity was higher in the summer months than in the other months, particularly in the CZ5 , where the humidity values were remarkably higher than those seen in the other climate zones, due to the hot and humid weather conditions present there. Furthermore, the exhaled air in the CZ-5 was almost saturated. For example, according to the calculation of metabolic heat energy production for 1 Met in the CZ-5, the exhaled air temperature and specific humidity in August were $35.11{ }^{\circ} \mathrm{C}$ and 0.0333 $\mathrm{kg} \mathrm{H}_{2} \mathrm{O} / \mathrm{kg}$ dry air, respectively. The relative humidity of exhaled air was $91.3 \%$, with near saturation at $101 \mathrm{kPa}$ atmospheric pressure.

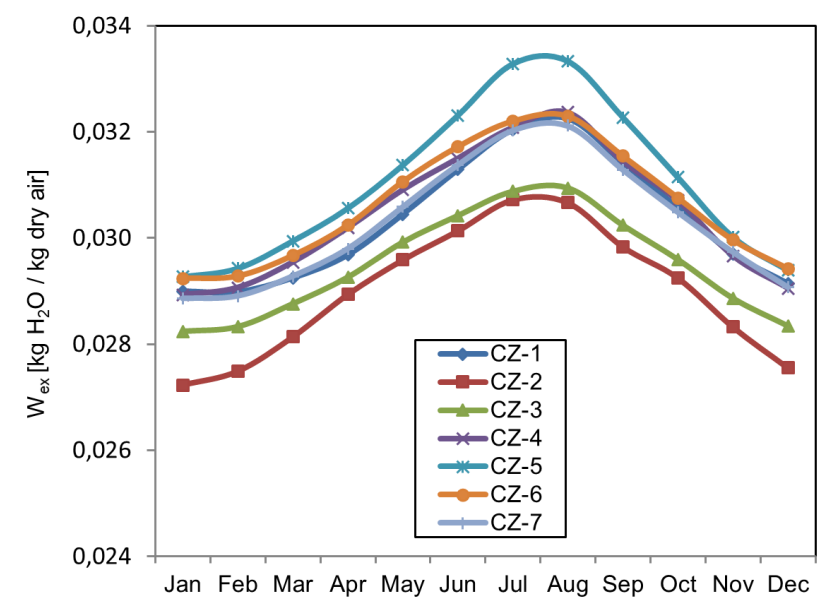

Fig. 5 The monthly variation of specific exhaled air humidity for 1 Met

The variations in heat loss and exergy flow via respiration according to different activity levels of an individual's body are presented in Figure 6. In this figure, when the activity

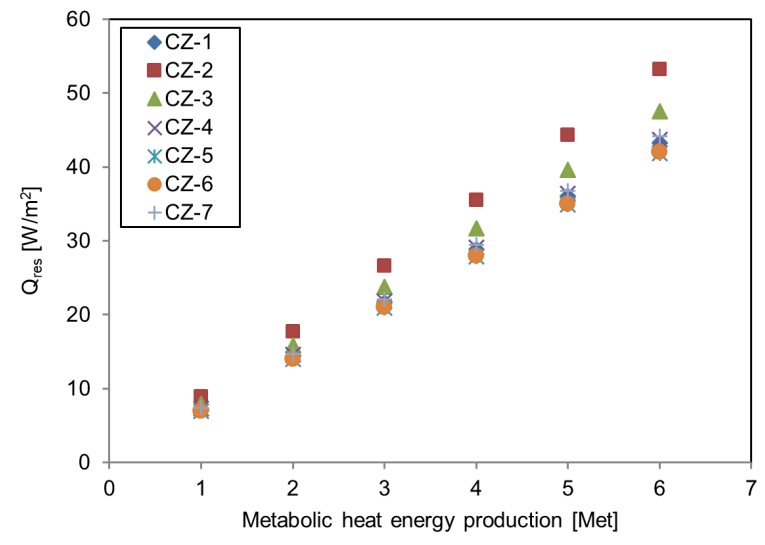

(a)

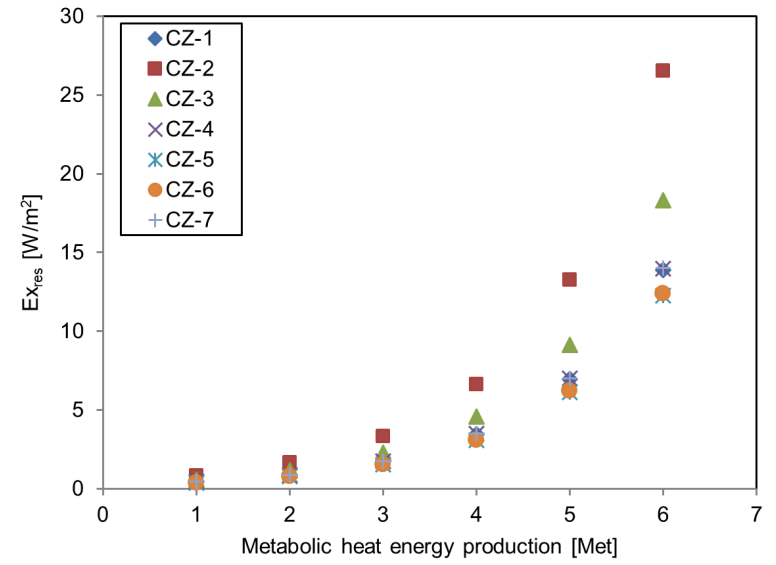

(b)

Fig. 6 The variation in (a) heat loss (b) exergy flow by respiration according to different activity levels of an individual's body

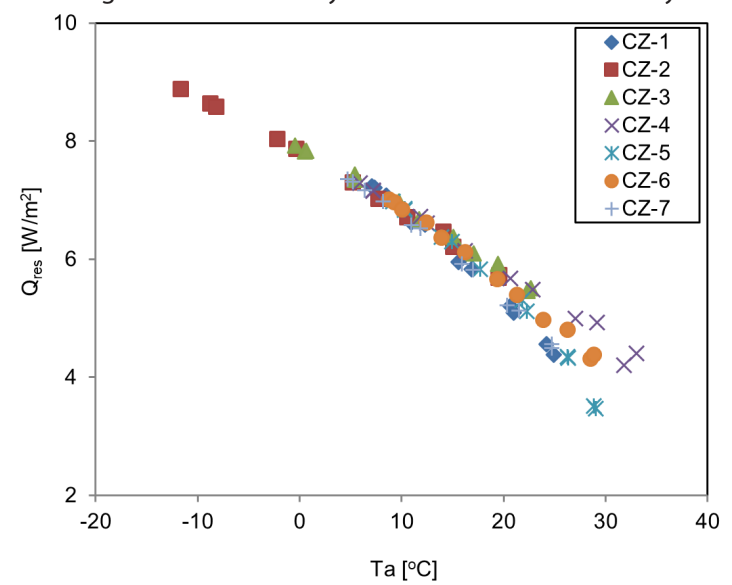

(a)

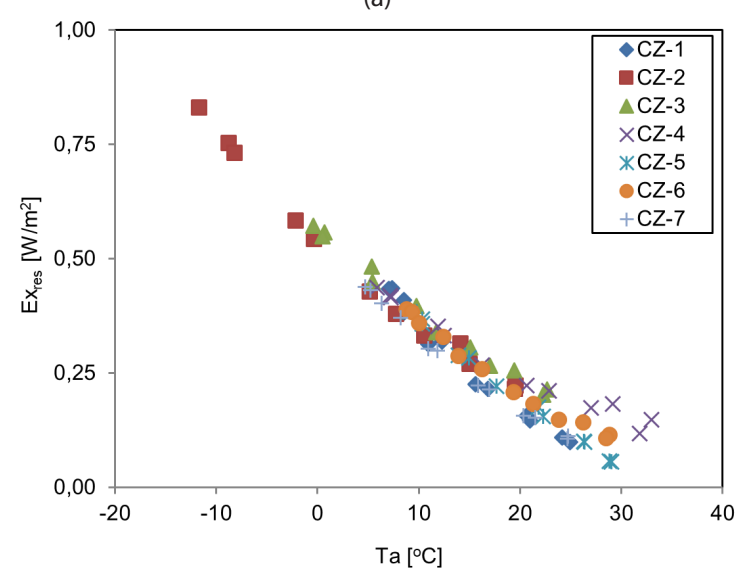

(b)

Fig. 7 Variation in (a) heat loss rate (b) exergy flow of respiration according to ambient temperature for metabolic heat energy production 
level rises, heat loss and also exergy flow by means of respiration increase. These results are good agreement with the study conducted by the authors [1]. For instance, heat transfer by respiration with metabolic heat energy production of 1 Met and 6 Met in the CZ-2 in January was found to be 8.88 $\mathrm{W} / \mathrm{m}^{2}$ and $53.26 \mathrm{~W} / \mathrm{m}^{2}$, respectively. Figures 7 and 8 show the heat loss and exergy flow rates of respiration, according to ambient temperature and specific humidity in the different climate zones, for metabolic heat energy production of 1 Met. As seen from these figures, the heat loss and exergy flow rates of respiration are inversely proportional with ambient temperature and specific humidity. In other words, the heat loss and exergy flow rates of respiration decrease when ambient temperature and specific humidity increase.

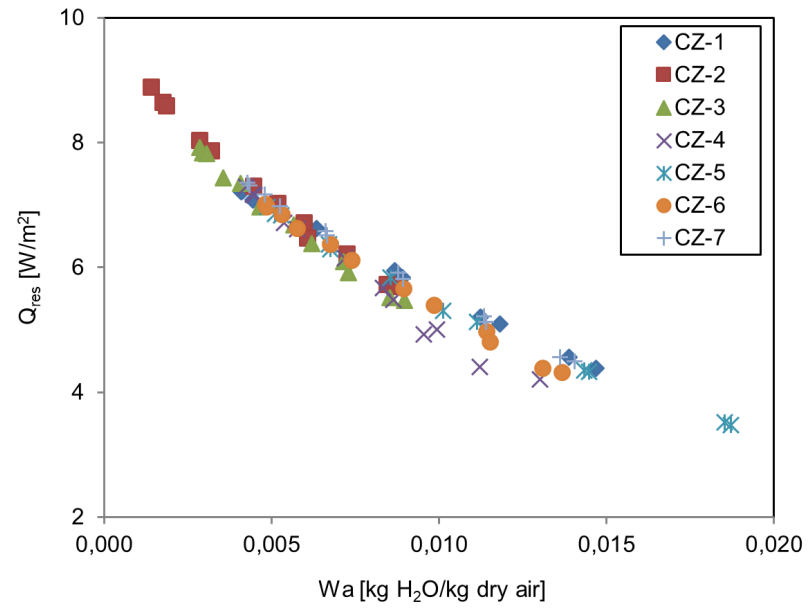

(a)

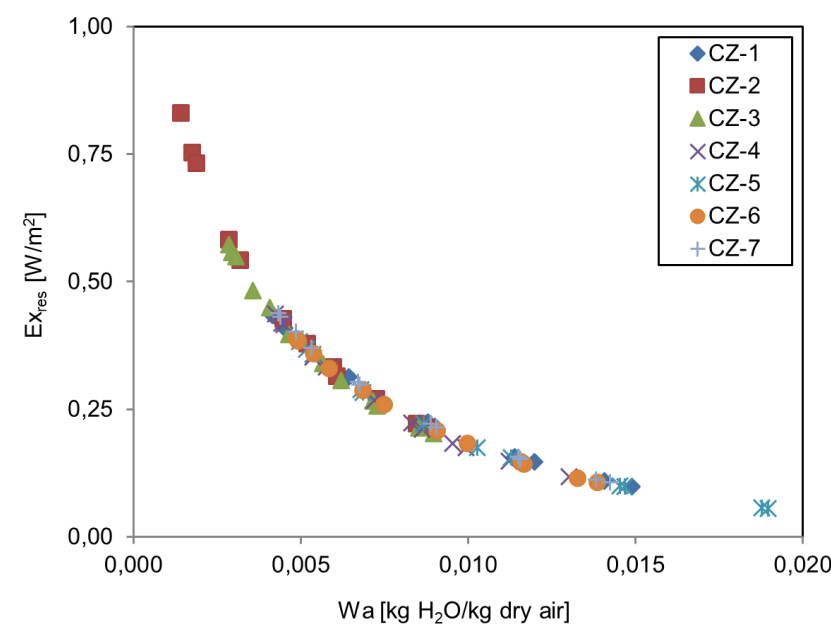

(b)

Fig. 8 Variation in heat transfer rate of respiration according to specific humidity for metabolic heat energy production of 1 Met

\section{CONCLUSIONS}

In this study, monthly total heat loss (evaporative and convective heat losses) and exergy flow that occur as a result of respiration are determined for human bodies in states of light and heavy activity levels. Heat loss and exergy flow occurring through the respiration of human body are a vital concern in terms of thermal comfort and health. According to the obtained results, total heat loss and exergy flow through the respiration of human body are significantly af- fected by seasonal and environmental changes. During inhalation, the evaporative heat loss is greater than the convective heat loss through respiration. An increase of ambient temperature results in a reduction of convective heat loss through respiration. When specific humidity of ambient air decreases, the evaporative heat loss through respiration increases. A human body engaging in the winter season transfers more heat to the environment by inhalation in comparison to other months. Total heat transfer via respiration, with metabolic heat energy production of 1 Met and 6 Met, are calculated as $8.88 \mathrm{~W} / \mathrm{m}^{2}$ and $53.26 \mathrm{~W} / \mathrm{m}^{2}$, respectively, for cold weather conditions. For a human body engaging in light activity in a hot climate zone, the exhaled air temperature and specific and relative humidity are determined as 35.11 ${ }^{\circ} \mathrm{C}, 0.0333 \mathrm{~kg} \mathrm{H}_{2} \mathrm{O} / \mathrm{kg}$ dry air and $91.3 \%$, respectively. In this climatic zone, exhaled air is almost saturated. The heat loss and exergy flow rates of respiration are inversely proportional with ambient temperature and specific humidity. The highest heat loss and exergy flow values are in the region of continental climate, while the lowest exergy flow values are in the region of Mediterranean climate. The results obtained from this present study may be used as a reference for a detailed study of air-conditioning applications.

\section{REFERENCES}

[1] Parsons K. (2002). Human Thermal Environments. CRS Press, third ed. Taylor \& Francis Group, New York.

[2] ASHRAE, Handbook Fundamentals (1993) American Society of Physiology and Human Environment. Inc, Atlanta, USA.

[3] Licina, D., Melikov, A.K., Sekhar, C., Tham, K.W. (2015). Air temperature investigation microenvironment around a human body. Building and Environment, 92: 39-47, DOI: 10.1016/j.buildenv.2015.04.014.

[4] Caliskan, H. (2013). Energetic and exergetic comparison of the human body for the summer season. Energy Conversion and Management, 76: 169-176, DOI:10.1016/j.enconman.2013.07.045.

[5] Mady, CEK., Ferreira, M.S., Yanagihara, J.I., Saldiva, P.H.N., Junior, S.O. (2012). Modeling the exergy behavior of human body. Energy, 45: 546-553, DOI: 10.1016/j.energy.2012.02.064.

[6] Wang, F., Zhang, C., Lu, Y. (2015). Correction of the heat loss method for calculating clothing real evaporative resistance. Journal of Thermal Biology, 52: 45-51, DOI:10.1016/j.jtherbio.2015.05.004.

[7] Thellier, F., Monchoux, F., Spagnol, S., Sassi, M.B. (2009). Measurement of ambient air temperature for evaluation of human heat convective losses. Measurement, 42: 62-70, DOl: 10.1016/j.measurement.2008.04.001.

[8] Li, C., Ito, K. (2014). Numerical and experimental estimation of convective heat transfer coefficient of human body under strong forced convective flow. Journal of Wind Engineering \& Industrial Aerodynamics, 126: 107-117, DOI: 10.1016/j.jweia.2014.01.003.

[9] White, M.D., Cabanac, M., (1995). Respiratory heat loss and core temperatures during submaximal exercise. Journal of Thermal Biology, 20: 489-496, DOl:10.1016/0306-4565(95)00011-K.

[10] Wu, X., Zhaoa, J., Olesen, B.W., Fang, L. (2013). A novel human body exergy consumption formula to determine indoor thermal conditions for optimal human performance in office buildings. Energy and Buildings, 56: 48-55, DOl:10.1016/j.enbuild.2012.10.010. 
[11] Celik, N., Bayazit, Y. (2008). The effect of individual differences on thermo-regulation in human body simulations. Journal of Thermal Science and Technology, 28: 17-22.

[12] Ferreira, M.S., Yanagihara, J.I. (2009). A transient three-dimensional heat transfer model of the human body. International Communications in Heat and Mass Transfer, 36: 718-24, DOI: 10.1016/j.icheatmasstransfer.2009.03.010.

[13] Gebremedhin, K.G., Wu, B. (2002). Simulation of sensible and latent heat losses from wet-skin surface and fur layer. Journal of Thermal Biology, 27: 291-297, DOI: 10.1016/S0306-4565(01)00091-2.

[14] Mady, C.E.K., Albuquerque, C., Fernandes, T.L., Hernandez, A.J., Saldiva, P.H.N., Yanagihara, J.I., Oliveira, Jr.S. (2013). Exergy performance of human body under physical activities. Energy, 62: 370-378, DOI: 10.1016/j.energy.2013.09.050

[15] Fanger PO (1970) Thermal comfort analysis and applications in environmental engineering, McGraw-Hill, New York.

[16] Fanger PO (1982) Thermal Comfort, Robert E. Krieger Publishing Company, Malabar, FL.

[17] Bilgili, M., Simsek, E., Sahin, B., Yasar, A., Ozbek, A., (2015). Estimation of human heat loss in five Mediterranean regions. Physiology and Behavior, 149: 61-68, DOI:10.1016/j.physbeh.2015.05.027. 